\title{
Erratum to: Assessing host specialization of Erysiphe pisi on garden pea germplasm through genotypic and phenotypic characterization
}

\author{
Malathi Bheri - Gemmalamadugu Fareeda • \\ Ragiba Makandar
}

Published online: 13 October 2016

(C) Springer Science+Business Media Dordrecht 2016

\section{Erratum to: Euphytica DOI 10.1007/s10681-015-1511-3}

While having the paper published online it came to the attention of the authors that some crucial parts in the Materials and methods section were missing. This information is supplied in this addendum so as to complete the Materials and methods section of the original paper.

\section{Materials and methods}

Source of Ep01 isolate Erysiphe pisi infected leaves of Arkel var. were collected from the Plant Culture facility of University of Hyderabad, Hyderabad, India (Lat. and Long.- $17.458209^{\circ} \mathrm{N}, 78.331345^{\circ} \mathrm{E}$ ).

The online version of the original article can be found under doi:10.1007/s10681-015-1511-3.

Electronic supplementary material The online version of this article (doi:10.1007/s10681-016-1719-x) contains supplementary material, which is available to authorized users.

M. Bheri · G. Fareeda · R. Makandar $(\bowtie)$

Department of Plant Sciences, School of Life Sciences,

University of Hyderabad, Prof. C.R.Rao Road,

Gachibowli, Hyderabad 500046, India

e-mail: mragiba@gmail.com;

rmsl@uohyd.ernet.in
Symptoms The fungal pathogen was identified visually by its characteristic white powdery appearance and an epiphytic mycelium on the infected plants.

Identification of pathogen through ITS based approach

DNA isolation, PCR amplification and sequencing The isolate used in this study was identified through the ITS sequence using fungal as well as Erysiphe specific primers. Erysiphe pisi infected pea leaves showing anamorphic stage were used for identification. DNA was isolated according to the modified method of Saghai-Maroof et al. (1984) wherein Isoamyl alcohol was used instead of octanol. The ITS region was amplified and sequenced using primer pairs: ITS1F (Gardes and Bruns 1993) and ITS4 (White et al. 1990) and Erysiphe specific primers: EryF \& EryR (Attanayake et al. 2009). Each PCR reaction consisted of $1 \times$ Taq buffer, $1.5 \mathrm{mM} \mathrm{MgCl}_{2}$, $0.25 \mathrm{U}$ Taq DNA polymerase, $200 \mu \mathrm{M}$ total dNTPs, $10 \mu \mathrm{mol}$ each of forward and reverse primers and $10 \mathrm{ng}$ of genomic DNA. The program was as follows: an initial denaturation at $94{ }^{\circ} \mathrm{C}$ for $7 \mathrm{~min}$ followed by 35 cycles of $95^{\circ} \mathrm{C}$ for $1 \mathrm{~min}$, an annealing temperature of $55{ }^{\circ} \mathrm{C}$ in case of ITS1F-ITS4 and $52{ }^{\circ} \mathrm{C}$ for EryFEryR for $1 \mathrm{~min}$, extension at $72{ }^{\circ} \mathrm{C}$ for $1.5 \mathrm{~min}$ with a final extension at $72{ }^{\circ} \mathrm{C}$ for $10 \mathrm{~min}$ followed by storage at $4{ }^{\circ} \mathrm{C}$. The amplicons were resolved on $1.2 \%$ agarose gels with Tris-acetate EDTA buffer (40 mM Tris-acetate, $1 \mathrm{mM}$ EDTA) at $75 \mathrm{~V}$ (constant 
voltage). PCR amplification of DNA resulted in expected amplification. The amplified PCR products were excised and eluted using NucleoSpin Gel and PCR Clean-up kit (Macherey-Nagel) and sequenced in both forward and reverse directions.

The forward sequences were aligned with the reverse complement of the reverse sequences using Clustal omega to get the complete sequence. The sequences were searched for highly similar sequences in NCBI using BLASTn. The sequences obtained using Erysiphe and fungal specific primers were found to show direct hits with Erysiphe species and were submitted in GenBank with the accession nos., KM096758.1 (sequence obtained using fungal specific primers, ITS1-F \& ITS4) and KM189823.1 (sequence obtained using Erysiphe specific primers, EryF \& EryR). The fungus was sent for identification to Department of Plant Pathology, Indian Agricultural Research Institute, New Delhi for an external confirmation. The same is provided as Supplementary information 1.

Disease phenotyping The disease was scored visually based on percentage leaf infection using the method proposed by Gawande and Patil (2003). A visual representation of the same is provided as Supplementary Fig. 1.

Though scoring for the disease spread in garden pea lines under study was carried through individual disease phenotyping based on percent disease Index (PDI) values, however, to ensure the presence of the fungal spread in infected pea leaves, trypan blue staining was also carried out during early stages of infection. The trypan blue-stained leaves of garden pea lines when compared for fungal spread by visualization under uniform magnifying field area showed significant differences among the disease categories. Therefore, to represent the visual variation observed among different categories, randomly chosen microscopic images were presented. Since the experiment was only to characterize the powdery mildew growth on pea plants through phenotypic studies, the fungal growth quantification does not seem to be relevant in this case.

Percent disease indices The PDI values from individual replications are shown in Supplementary Table 1 . The leaf infection was graded using the $0-5$ scale of Gawande and Patil (2003). The PDI values were calculated using the formula proposed by Wheeler (1969). The graph shows the mean \pm SE values. A zero PDI value indicates no fungal growth. The uniform values of $20 \pm 0.0 / 40 \pm 0.0$ were obtained due to the score allotted for leaf infections in the range of 1-10 and 11-25\% respectively.

\section{References}

Attanayake RN, Glawe DA, Dugan FM, Chen W (2009) Erysiphe trifolii causing powdery mildew of lentil (Lens culinaris). Plant Dis 93:797-803

Gardes M, Bruns TD (1993) ITS primers with enhanced specificity for basidiomycetes application to the identification of mycorrhizae and rusts. Mol Ecol 2:113-118

Gawande VL, Patil JV (2003) Genetics of powdery mildew (Erysiphe polygoni DC.) resistance in mungbean (Vigna radiata (L.) Wilezck). Crop Protect 22:567-571

Saghai-Maroof MA, Soliman KM, Jorgensen RA, Allard RW (1984) Ribosomal DNA spacer-length polymorphisms in barley: Mendelian inheritance, chromosomal location, and population dynamics. Proc Natl Acad Sci 81(24): 8014-8018

Wheeler BEJ (1969) An introduction to plant disease. Wiley, London

White TJ, Bruns TD, Lee S, Taylor J (1990) Amplification and direct sequencing of fungal ribosomal RNA genes for phylogenetics. In: Innis M, Gelfand D, Sninsky J, White T (eds) PCR protocols: a guide to methods and applications, Chap. 38. Academic Press, Orlando, pp 315-322 